\title{
Role of Coarse and Fine Mode Aerosols in MODIS AOD Retrieval: a case study over southern India
}

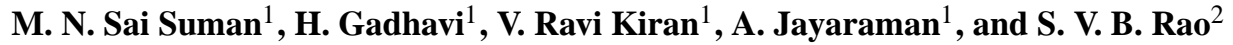 \\ ${ }^{1}$ National Atmospheric Research Laboratory, Gadanki, 517 112, India \\ ${ }^{2}$ Sri Venkateswara University, Tirupati, 517 502, India \\ Correspondence to: H. Gadhavi (harish.gadhavi@gmail.com; harish@narl.gov.in) \\ Received: 13 August 2013 - Published in Atmos. Meas. Tech. Discuss.: 24 October 2013 \\ Revised: 14 February 2014 - Accepted: 19 February 2014 - Published: 4 April 2014
}

\begin{abstract}
In the present study we compare the MODIS (Moderate Resolution Imaging Spectroradiometer) derived aerosol optical depth (AOD) data with that obtained from operating sky-radiometer at a remote rural location in southern India (Gadanki, $13.45^{\circ} \mathrm{N}, 79.18^{\circ} \mathrm{E}$ ) from April 2008 to March 2011. While the comparison between total (coarse mode + fine mode) AODs shows correlation coefficient $(R)$ value of about 0.71 for Terra and 0.77 for Aqua, if one separates the AOD into fine and coarse mode, the comparison becomes very poor, particularly for fine mode with an $R$ value of 0.44 for both Terra and Aqua. The coarse mode AOD derived from MODIS and sky-radiometer compare better with an $R$ value of 0.74 for Terra and 0.66 for Aqua. The seasonal variation is also well captured by both ground-based and satellite measurements. It is shown that both the total AOD and fine mode AOD are significantly underestimated with slope of regression line 0.75 and 0.35 respectively, whereas the coarse mode AOD is overestimated with a slope value of 1.28 for Terra. Similar results are found for Aqua where the slope of the regression line for total AOD and fine mode AOD are 0.72 and 0.27 whereas 0.95 for coarse mode. The fine mode fraction derived from MODIS data is less than one-half of that derived from the sky-radiometer data. Based on these observations and comparison of single scattering albedo observed using sky-radiometer with that of MODIS aerosol models, we argue that the selection of aerosol types used in the MODIS retrieval algorithm may not be appropriate particularly in the case of southern India. Instead of selecting a moderately absorbing aerosol model (as being done currently in the MODIS retrieval) a more absorbing aerosol model could be a better fit for the fine mode aerosols, while reverse is true for the coarse mode aerosols, where instead
\end{abstract}

of using "dust aerosols" which is relatively absorbing type, usage of coarse sea-salt particles which is less absorbing is more appropriate. However, not all the differences could be accounted based on aerosol model, other factors like errors in retrieval of surface reflectance may also be significant in causing underestimation of AOD by MODIS.

\section{Introduction}

Detailed knowledge on atmospheric aerosols is necessary as they play a very important role in determining Earth's radiation budget by scattering and absorbing incoming solar radiation and by modifying cloud microphysical properties (Haywood and Boucher, 2000; Ramanathan et al., 2001). Their ability to influence Earth's radiation budget as well as their effects on health, air quality and clouds significantly depends on their size (Ruzer and Harley, 2004; Dusek et al., 2006). Aerosol size distribution in turn depends on their production mechanism, e.g. particles formed by gas-to-particle conversion are small particles whereas particles formed by mechanical actions such as wind lifting of dust, wave-breaking, etc. are bigger in size. Particles which are produced as a result of human activities are in-general smaller in size and the naturally produced particles are in general bigger in size. Hence the ability to differentiate particles with respect to their size can provide a mean to quantify the influence of human activities on the abundance of atmospheric aerosols. Separating contributions from smaller and bigger particles in aerosol optical depth (AOD) is a step forward in this direction and can serve as a proxy to study many 
of the effects discussed above (Kosmopoulos et al., 2008; Lee et al., 2010; Kaskaoutis et al., 2012; Sinha et al., 2012).

Separating contributions from smaller and bigger particles to AOD requires knowledge on size distribution (number concentration as a function of particle radius) and bulk refractive index of particles. Methods exist that can derive these two parameters from spectral observation of AOD and sky-radiances from ground-based sky-radiometer (Nakajima et al., 1996; Dubovik and King, 2000; O'Neill et al., 2003). However, both the size distribution and the refractive index of aerosol are highly variable in space and time. Hence, spaceborne platforms are necessary to observe aerosol properties over global or continental scale. A considerable progress has been made to estimate AOD from space-borne platforms in past two decades (Martonchik et al., 1998; Ignatov et al., 2004; Remer et al., 2005, 2008; Kokhanovsky et al., 2007; Laszlo et al., 2008; Livingston et al., 2009; Kahn et al., 2010; Tanré et al., 2011; Hsu et al., 2012). However, only few satellite sensors are able to provide AOD over land and the retrieval of other aerosol properties like size distribution, single scattering albedo or refractive-index remains to be a challenging task. MODIS (Moderate Resolution Imaging Spectroradiometer) on-board Terra and Aqua, MISR (Multiangle Imaging Spectroradiometer) on-board Terra and OMI (Ozone Monitoring Instrument) on-board Aura satellites are currently operational satellite sensors which provide estimates of AOD over land (Torres et al., 2007; Remer et al., 2008; Kahn et al., 2010). Besides, AOD, there are several other atmospheric parameters that are retrieved from MODIS, of which fine mode fraction of AOD is of particular interest in the present context. However, the fine mode fraction from MODIS is still an experimental product and it has been advised that discretion must be exercised to use it for scientific purpose (Levy et al., 2010). Levy et al. (2010) mention that the fine mode fraction (referred as weighting parameter ETA in their article) have little physical validity and primarily reflect algorithm assumption about particle type. This is an important attribute of this parameter and its importance despite its less physical validity stands-out as a variable that could be used to diagnose deficiencies in the algorithm and improve the AOD retrieval.

Algorithm to retrieve fine mode fraction is described in Levy et al. (2007). Inversion of MODIS measured radiances to estimate AOD requires assumption regarding aerosol type and size distribution. The columnar aerosol size distribution is assumed to be bimodal which is a combination of one fine mode and one coarse mode aerosol type. One of the three aerosol types namely "non-absorbing type", "absorbing type" and "moderately absorbing type" is selected for fine mode aerosol based on place and season of the measurement and "dust type" is selected for coarse mode aerosols. Proportion of two aerosol models (types) in terms of AOD at $0.55 \mu \mathrm{m}$ is selected such that the difference between calculated reflectances and the reflectances measured by MODIS at $0.47 \mu \mathrm{m}$ are zero and the difference at $0.66 \mu \mathrm{m}$ is minimum.
The weighting parameter thus obtained between fine mode and coarse mode aerosols is fine mode fraction of AOD at $0.55 \mu \mathrm{m}$ (Levy et al., 2007).

There are several factors that affect the retrieval accuracy of fine mode fraction. The weighting parameter (or fine mode fraction) is not determined as a continuous variable but a value from the set of 11 discrete values between zero and one. There are only four (three fine mode and one coarse mode) aerosol models to select from on a global scale. Inaccuracies in spectral surface reflectance estimates have bearing on spectral AOD retrieval (Jethva et al., 2010). These are a few of various factors that affect accuracy of MODIS fine mode fraction. Objective of the current study is to examine the dynamics of aerosol size-distribution in terms of fine mode fraction of AOD over a tropical continental and remote location (Gadanki; $13.45^{\circ} \mathrm{N}, 79.18^{\circ} \mathrm{E}$ ) and to validate MODIS derived fine mode fraction with ground-truth data obtained using a sky-radiometer. Along with size resolved properties, present study also compares the MODIS total AOD against ground measurements.

\section{Site-Description and instrumentation}

Observations of AOD, columnar size-distribution and column integrated refractive-index are regularly being carried out using a sky-radiometer (Model: POM-01, Prede Co. Ltd., Japan) from a rural and remote site in southern India (Gadanki; $\left.13.45^{\circ} \mathrm{N}, 79.18^{\circ} \mathrm{E}\right)$. The place has, in general, a tropical wet climate. It is strategically located in the peninsular India where it experiences two entirely different air-masses, from the southwest during summer (June to August) and from the northeast during winter (December to February). Climatological mean relative humidity and wind stream lines over South Asia are shown in Fig. 1 for January and July months using NCEP re-analysis data (Kalnay et al., 1996). Location of Gadanki is shown with a white star on the map. Air-masses coming from the northeastern direction via the Bay of Bengal are expected to be rich in anthropogenic aerosols whereas the air-masses coming from the Indian Ocean are expected to be rich in natural aerosols (Corrigan et al., 2006; Jayaraman et al., 2006; Suresh Babu et al., 2007; Rajeev et al., 2010).

\subsection{Sky-radiometer}

The sky-radiometer measures direct solar radiation at one minute intervals and sky-radiances at fixed angles with respect to the sun at $10 \mathrm{~min}$ interval. While both direct and the sky-radiances can be used to retrieve AOD, in the present study, we have used AOD retrieved using sky-radiances only as the AOD retrieval from sky-radiances does not depend on absolute radiation measurements and hence suitable for long-term studies (Nakajima et al., 1996). The AOD observations are made at 5 wavelengths viz. 400, 500, 675, 
(a)

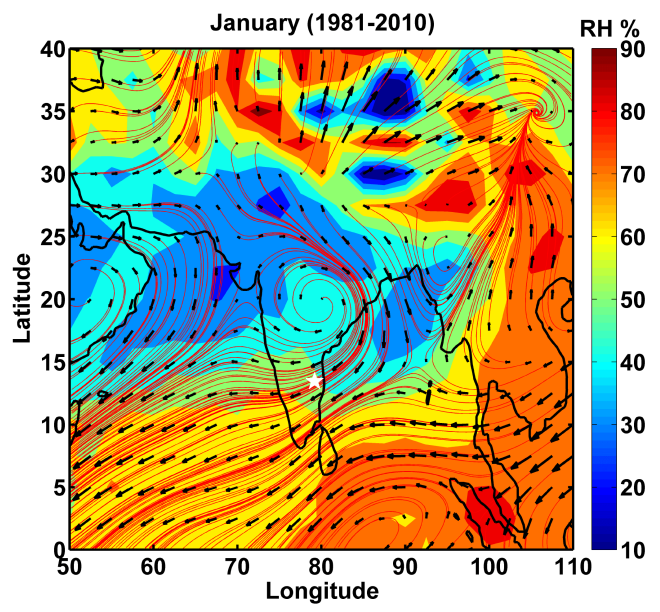

(b)

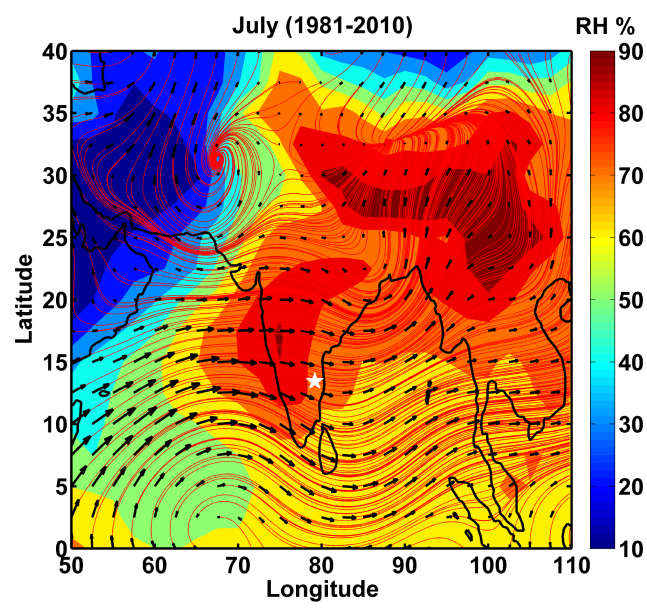

Fig. 1. Climatological wind stream line overlaid over climatological relative humidity over South Asia based on NCEP reanalysis data.

870 and $1020 \mathrm{~nm}$. SKYRAD.PACK (Henceforth referred as SKYRAD) software which is used to retrieve AOD and other aerosol optical properties is based on Nakajima et al. (1996). Correction for Rayleigh optical depth is done using daily mean pressure values and correction for ozone optical depth at $400 \mathrm{~nm}$ channel is done using OMI columnar ozone values over Gadanki. Though the algorithm takes care of cloud contamination using in-built threshold checks, in the present study, all data points are also manually inspected for consistency using log-book entries on cloud conditions. Overall error in AOD retrieval is estimated to be $5.5 \%$ at $500 \mathrm{~nm}$ and $8.4 \%$ at $1020 \mathrm{~nm}$ based on estimates of errors in inputs and their forward propagation in the algorithm. The instrument has been used before to study radiative forcing over Gadanki (Gadhavi and Jayaraman, 2010). AOD observations over Gadanki are available from April 2008 to March 2011. Same algorithm is used to retrieve columnar size distribution and refractive indices. Kim et al. (2004) using sensitivity analysis have shown that the SKYRAD algorithm is highly accurate for retrieving volume concentration of particles in size range 0.1 to $10 \mu \mathrm{m}$. Estellés et al. (2012) have compared columnar volume size distribution by SKYRAD and AERONET and found that on an average they differ by about $13 \%$ for particle radius between 0.15 to $5 \mu \mathrm{m}$. Che et al. (2008) have compared AOD and single scattering albedo (SSA) from Prede (SKYRAD) and CIMEL sun-photometer (AERONET) over Beijing, China and found that AODs between two instruments differed by less than $1.3 \%$ and SSA differed by less than $4 \%$.

\subsection{MODIS data}

The MODIS data used in this study are Level 3 Collection 5 data downloaded from NASA GIOVANNI website (http://disc.sci.gsfc.nasa.gov/giovanni, last accessed on 25 March 2013). MODIS Level 3 data are quality checked and globally gridded over $1^{\circ} \times 1^{\circ}$ grid resolution (Levy et al., 2009). Expected error over land in MODIS AOD is characterised as $\Delta \tau= \pm 0.05 \pm 0.15 \tau$, where $\tau$ is aerosol optical depth at $550 \mathrm{~nm}$ (Levy et al., 2007). There are certain inherent limitations of comparing ground-based AOD retrieval with satellite based AOD retrievals for example a typical skyradiometer has a narrow field-of-view and hence represents a smaller area, whereas satellite retrievals represent average over large foot print. This limitation can be partly compensated by time averaging ground-based data for a characteristic time for spatial resolution of satellite data (Ichoku et al., 2002). In this study, we have compared MODIS $1^{\circ} \times 1^{\circ}$ AODs with sky-radiometer AODs which are averaged over an interval of one hour around satellite overpass time. Normally, high resolution Level 2 data are used for comparison studies. However, in our previous study (Kiran Kumar et al., 2013), AOD over Gadanki is found to be spatially well correlated for the distances of the order of 150 to $200 \mathrm{~km}$. When AOD field is spatially homogeneous, it is advantageous to use Level 3 data since averaging reduces random noise and number of days with missing data. Values of skyradiometer AODs at $550 \mathrm{~nm}$ are estimated by linear interpolation of $\log$ of AODs at $500 \mathrm{~nm}$ and $675 \mathrm{~nm}$ on $\log$ of wavelengths. There have been several validation exercises worldwide using ground-based data including our own (Ichoku et al., 2002; Hauser et al., 2005; Remer et al., 2005; Tripathi et al., 2005; Jethva et al., 2007, 2010; Misra et al., 2008; El-Metwally et al., 2010; Levy et al., 2010; Kharol et al., 2011; Kiran Kumar et al., 2013) and majority of them report that the MODIS AOD compares with ground-based data within the above-stated expected error. However, Kharol et al. (2011) and we (Kiran Kumar et al., 2013) have reported a significant underestimation of AOD over the southern part of India by MODIS. Since our last study, we have collected more data using the sky-radiometer and a comparison of MODIS AODs with ground-truth data is shown in Fig. 2. Regression relationship between MODIS Terra and Aqua is 
(a)

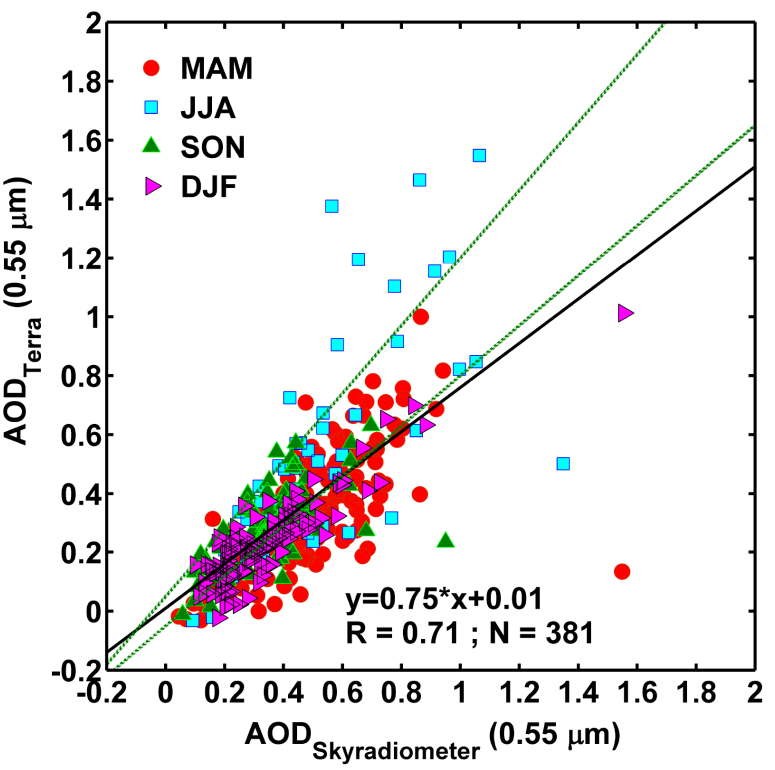

(b)

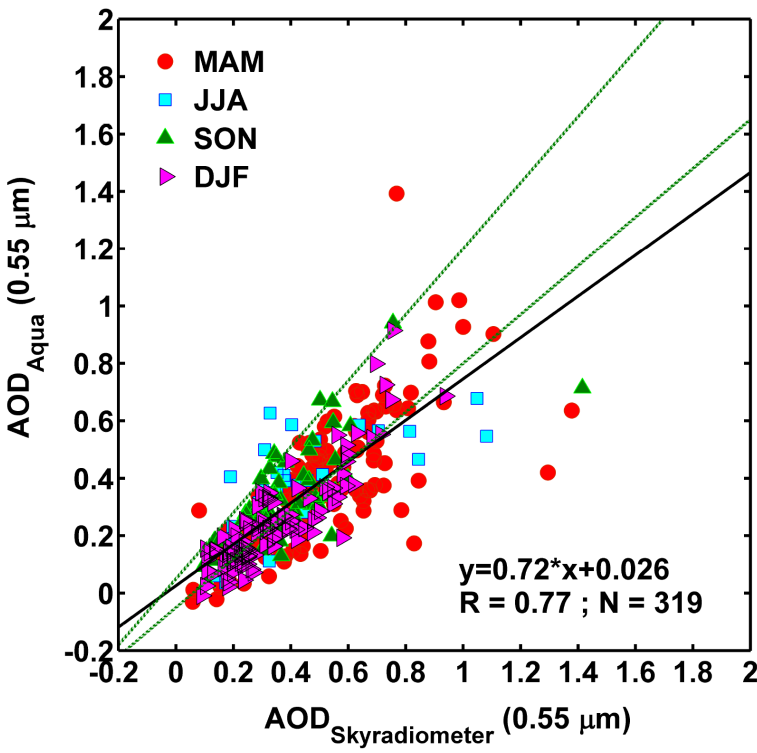

Fig. 2. Scatter plot (a) between MODIS-Terra and sky-radiometer AOD and (b) between MODIS-Aqua and sky-radiometer AOD over a rural location in southern India (Gadanki $13.45^{\circ} \mathrm{N}, 79.18^{\circ} \mathrm{E}$ ). Sky-radiometer AODs are averaged for one hour around satellite overpass time. Satellite AODs are averaged over $1^{\circ} \times 1^{\circ}$ grid-box over Gadanki. Black line in both the figures show the linear fit for which the equation is shown while green lines show the boundary of expected errors $(\Delta \tau= \pm 0.05 \pm 0.15 \tau)$ in MODIS AOD over land (Levy et al., 2007).

nearly the same $(y=0.75 \cdot x+0.01$ for Terra and $y=0.72$. $x+0.026$ for Aqua) with correlation coefficient $(R)$ values 0.71 and 0.77 for Terra and Aqua respectively. We suggest that the underestimation could be because of wrong aerosol model for absorbing properties. MODIS aerosol model for South Asia and particularly for southern India does not have

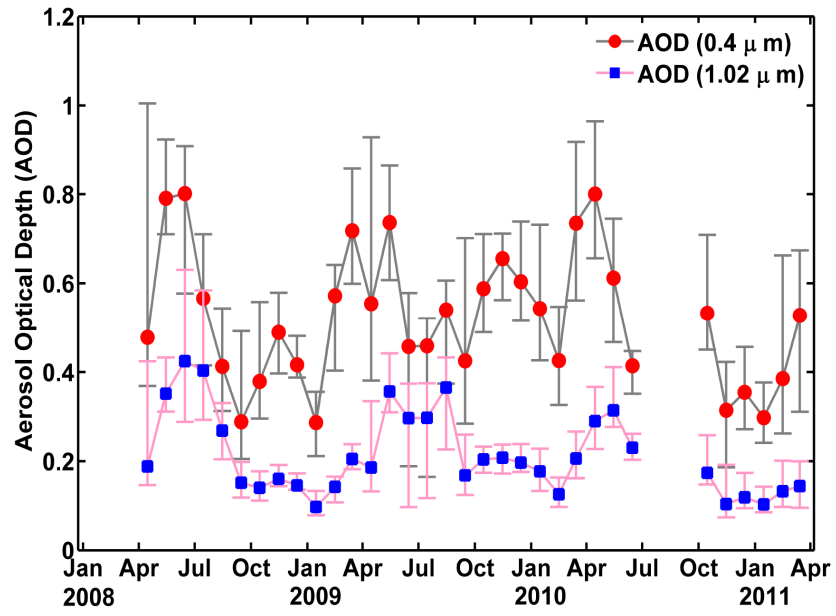

Fig. 3. Monthly median aerosol optical depth at $400 \mathrm{~nm}$ and $1020 \mathrm{~nm}$ derived from sky-radiometer data. Vertical bars are interquartile range.

sufficiently low single scattering albedo (ratio of scattering to scattering + absorption). It is important to know whether it is a problem with fine mode or coarse mode aerosol model since there are two aerosol models which have significant absorption in the visible region but with different size distribution. These are soot and dust aerosols, while soot particles are fine mode aerosols, dust particles are predominantly coarse mode aerosols. This aspect is examined in detail as reported below.

\section{Results and discussion}

Monthly median values of AOD at $400 \mathrm{~nm}$ and $1020 \mathrm{~nm}$ from sky-radiometer are shown in Fig. 3. Lower wavelength AOD values are more sensitive to smaller size particles and higher wavelength AOD values are more sensitive to coarse mode particles and forms the basis for retrieving columnar aerosol size distribution. A systematic seasonal variation of AOD at $1020 \mathrm{~nm}$ can be seen with high values close to 0.4 during May to August and low during October to February with values close to 0.1 . AOD at $400 \mathrm{~nm}$ also has seasonal variation but not as systematic as that observed for $1020 \mathrm{~nm}$. The difference between the 400 and $1020 \mathrm{~nm}$ AODs become minimum during June, July and August and maximum during November, December, March and April indicating that there are changes taking place in columnar aerosol size distribution.

As noted earlier, columnar size distribution is retrieved from the sky-radiometer measured radiances using SKYRAD algorithm in case of ground-based observations. The algorithm is based on Nakajima et al. (1996). Median columnar size distributions obtained for summer and winter periods are shown in Fig. 4. The volume sizedistribution is found to be predominantly bi-modal for most 
(a)

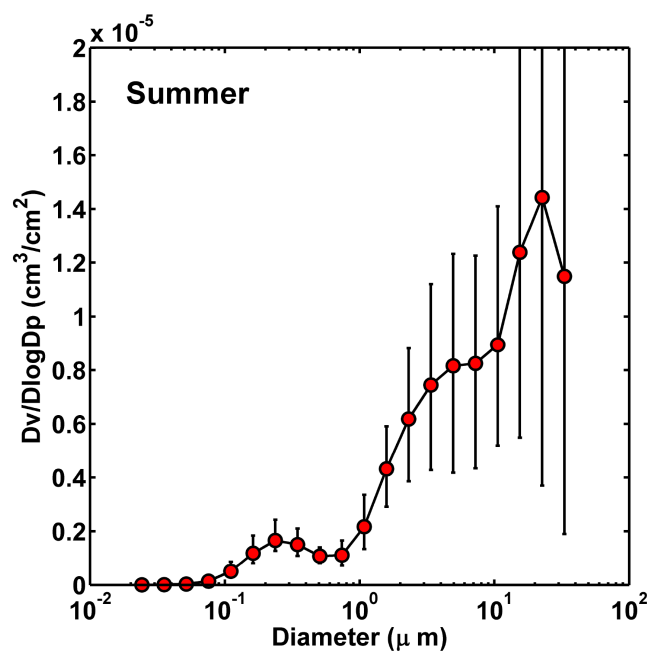

(b)

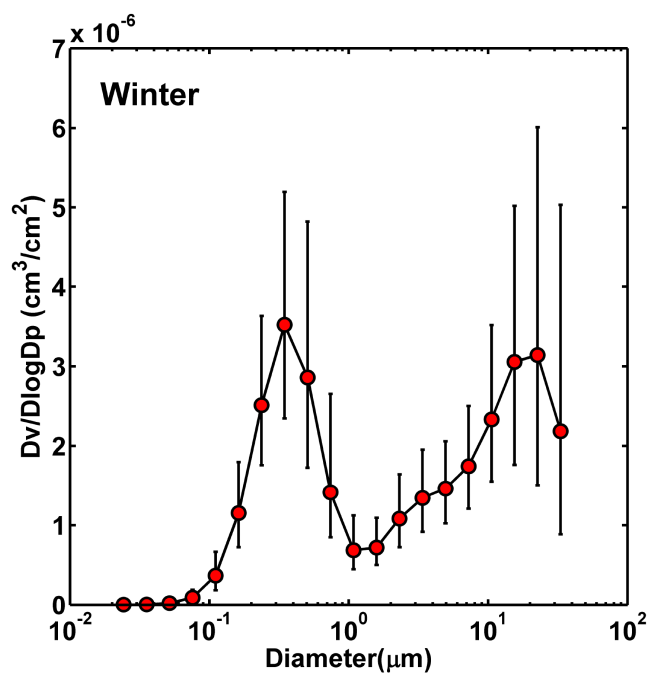

Fig. 4. Median columnar volume-size-distribution over Gadanki for (a) Summer and (b) Winter derived from the direct and sky-radiance measurements using the sky-radiometer. Vertical bars are interquartile range. Values of bar in summer plot going beyond $y$-axis range are $3.27 \times 10^{-5}, 8.21 \times 10^{-5}$ and $1.11 \times 10^{-4}$ for radii $7.73,11.31$ and $16.54 \mu \mathrm{m}$.

seasons with a clear dip between the two modes. Sinha et al. (2012) have studied aerosol size distribution from Hyderabad $\left(17.47^{\circ} \mathrm{N}, 78.58^{\circ} \mathrm{E}\right)$ - a major city in southern India and have also reported bi-modal size distribution using hand-held sun-photometer. The size distribution should be ideally split into two parts from centre of the dip. However, we have used a fixed radius of $0.6 \mu \mathrm{m}$ to separate fine mode and coarse mode AOD as $0.6 \mu \mathrm{m}$ is the closest to the dip for most seasons and also it is the convention followed for AERONET data (O'Neill et al., 2003). AODs are recalculated for each part separately using the Mie algorithm (Bohren and Huffman, 1983), and the refractive indices and

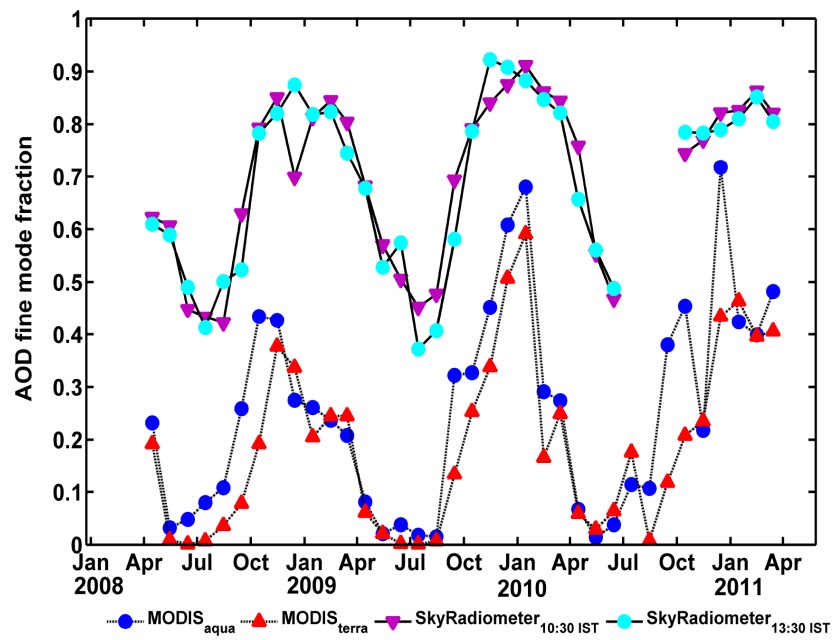

Fig. 5. Time series of monthly mean fine mode fraction over Gadanki derived using sky-radiometer data are compared with that given by MODIS Terra and Aqua payloads.

size-distribution retrieved by SKYRAD. Fine mode fraction is calculated as ratio of fine mode AOD to total (fine + coarse) AOD. Time series of fine mode fraction by sky-radiometer and MODIS are shown in Fig. 5. A prominent seasonal cycle in fine mode fraction values is evident from the figure. Fine mode fraction from sky-radiometer is as high as 0.9 during winter and never goes less than 0.4. The minimum fine mode fraction is observed during July. High fine mode fraction values are linked to airmasses coming from Indian subcontinent and low values of fine mode fraction are linked to airmasses coming from the northern Indian Ocean. MODIS fine mode fraction also captures the seasonal cycle but systematically underestimates the values. MODIS fine mode fraction values are less than one-half of sky-radiometer based values.

Seasonal changes in fine mode fraction can take place when anyone of the two AODs (fine mode AOD or coarse mode AOD) is changing, or both AODs are changing with two different seasonal patterns. In Fig. 6a, time-series of monthly mean coarse mode AOD from MODIS and skyradiometer are compared and in Fig. 6b, time-series of monthly mean fine mode AODs are compared. Coarse mode AOD has well defined seasonal variation with low values around 0.05 during January and high values between 0.3 and 0.4 from May to July. Peak coarse mode AOD is found decreasing during the three years period from 2008 to 2011 which is an interesting observation, but beyond the scope of the present study. There is a good match between skyradiometer and MODIS for coarse mode AODs, though the MODIS coarse mode AOD is high in most cases. The decrease in peak coarse mode AOD during three years from 2008 to 2011 is also observed in MODIS data. A scatter plot of daily coarse mode AOD from sky-radiometer and MODIS-Terra is shown in Fig. 7a. There is a good correlation $(R=0.74)$ but the slope of linear square fit is 1.3 with a 
(a)

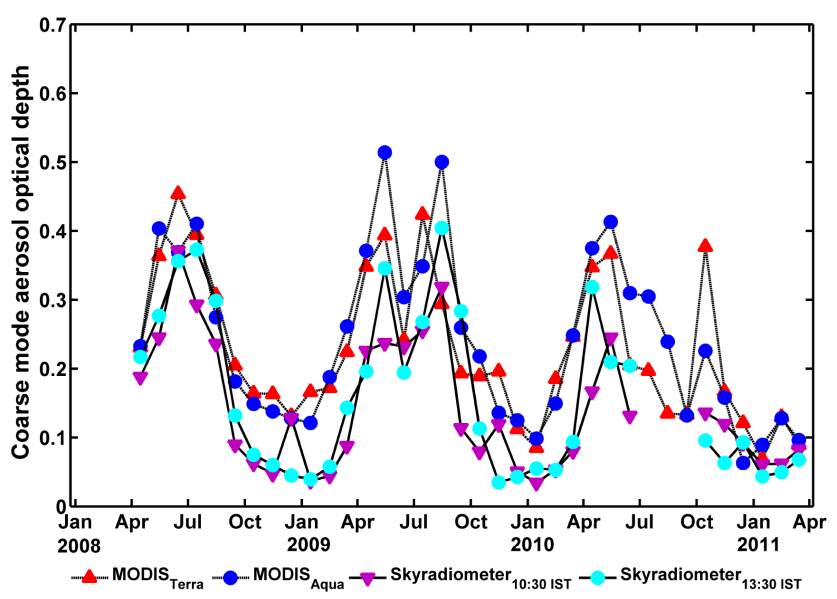

(b)

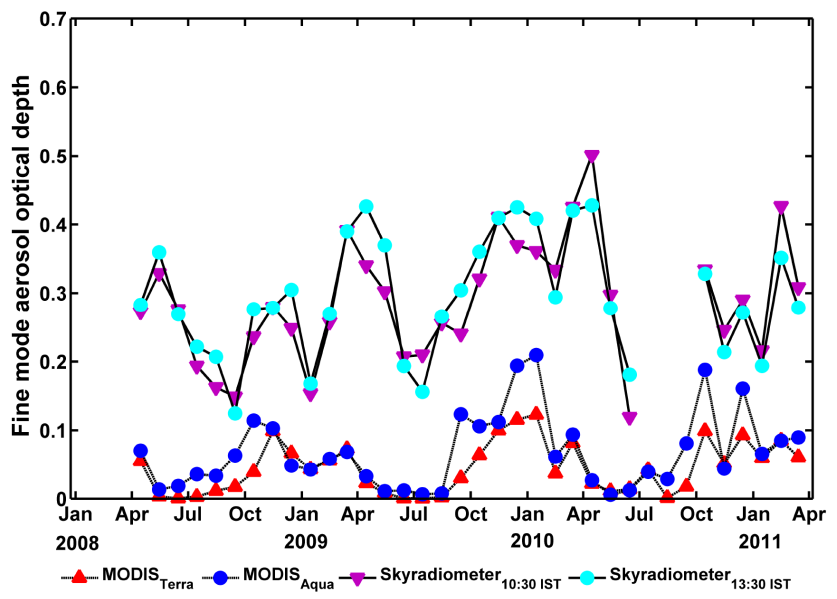

Fig. 6. Time series of monthly mean (a) coarse mode and (b) fine mode AODs obtained from sky-radiometer data over Gadanki are compared with that from MODIS Terra and Aqua payloads.

positive bias of 0.1 which imply a significant overestimation of coarse mode AOD in MODIS data. The match between MODIS and sky-radiometer fine mode AOD is rather poor ( $R=0.44$; Fig. $7 \mathrm{~b}$ ). MODIS significantly underestimates the fine mode AOD and it is the main cause for overall underestimation of AOD as shown in Fig. 2. MODIS fine mode AOD for a large part of the time-series is close to 0.05 and barely reaches 0.1 during winter, whereas sky-radiometer fine mode AOD never goes below 0.2. Another difference between MODIS fine mode AOD and sky-radiometer fine mode AOD as evident from Fig. $6 b$ is that a systematic maximum in fine mode AOD in case of sky-radiometer is observed during April-May which is absent in MODIS fine mode AOD. The correlations between sky-radiometer and MODIS coarse mode and fine mode AODs are season dependent. Their seasonal correlations along with MODIS total AODs are shown in Table 1. The highest correlation for Terra in case of coarse (a)

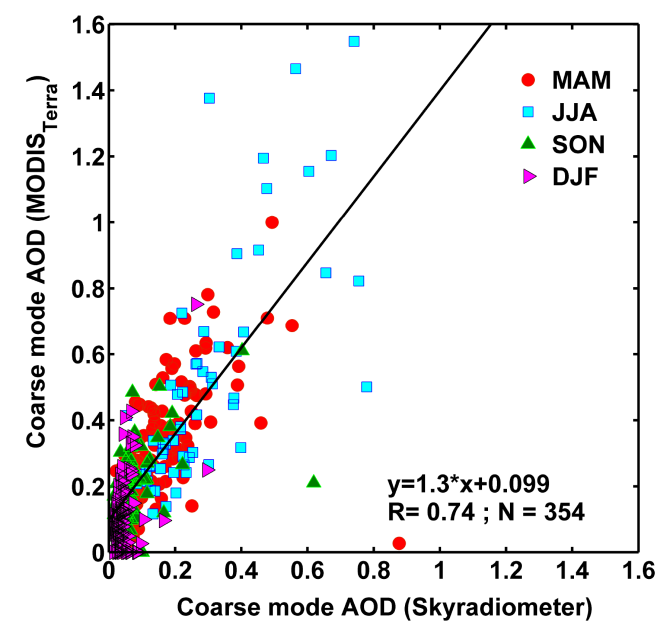

(b)

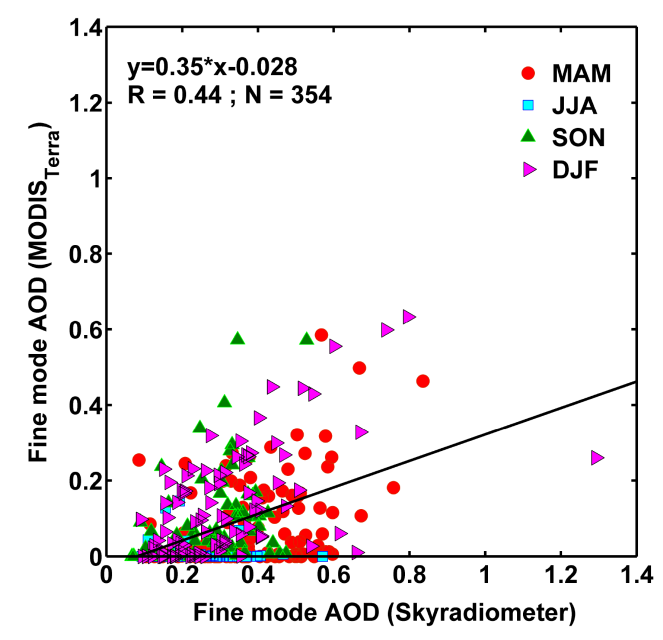

Fig. 7. Scatter plot of MODIS vs. sky-radiometer AOD for (a) coarse mode and (b) fine mode.

mode AODs is found during summer with value 0.75 and lowest correlation is found during autumn with value 0.4 . In case of Aqua, highest correlation for coarse mode is 0.74 during autumn and lowest 0.3 during winter. In case of fine mode AODs, the highest correlation is during winter and nearly zero correlation during summer for both the satellite sensors. Whereas in case of total (fine + coarse) AOD, the highest correlation is found during winter $(0.9)$ for both the satellite sensors and the lowest during autumn (0.6) for Terra and during summer (0.7) for Aqua. In-spite of good correlation in winter for total (fine + coarse) AOD, relatively poor correlation in coarse mode and fine mode AODs imply that errors in coarse and fine mode AODs are complementary to each other that is cancelling each other's effect on total AOD.

There has been a few studies in the past to validate the fine mode fraction using ground-based sky-radiometer data. Here, we mention only those which pertain to latest (C05) 
Table 1. Correlation coefficient $(R)$, root mean square difference (RMSD) and least square fit parameters between sky-radiometer and MODIS Terra and Aqua.

\begin{tabular}{|c|c|c|c|c|c|c|c|c|c|c|c|c|c|c|}
\hline \multirow[b]{3}{*}{ Seasons ${ }^{\mathrm{a}}$} & \multicolumn{14}{|c|}{ MODIS-Terra } \\
\hline & \multicolumn{5}{|c|}{ Total AOD } & \multicolumn{5}{|c|}{ Coarse mode AOD } & \multicolumn{4}{|c|}{ Fine mode AOD } \\
\hline & $N$ & $R$ & $a^{\mathrm{b}}$ & $b^{\mathrm{b}}$ & RMSD & $N$ & $R$ & $a^{\mathrm{b}}$ & $b^{\mathrm{b}}$ & RMSD & $R$ & $a^{\mathrm{b}}$ & $b^{\mathrm{b}}$ & RMSD \\
\hline MAM & 153 & 0.66 & 0.63 & 0.03 & 0.22 & 142 & 0.59 & 0.93 & 0.16 & 0.21 & 0.43 & 0.33 & -0.05 & 0.32 \\
\hline JJA & 61 & 0.72 & 1.00 & 0.00 & 0.24 & 58 & 0.75 & 1.47 & 0.10 & 0.33 & -0.07 & -0.02 & 0.01 & 0.24 \\
\hline SON & 70 & 0.62 & 0.54 & 0.10 & 0.15 & 66 & 0.40 & 0.55 & 0.16 & 0.17 & 0.37 & 0.42 & -0.02 & 0.22 \\
\hline DJF & 97 & 0.89 & 0.69 & 0.00 & 0.14 & 88 & 0.47 & 1.33 & 0.06 & 0.13 & 0.56 & 0.44 & 0.00 & 0.24 \\
\hline \multirow[t]{3}{*}{ Overall } & 381 & 0.71 & 0.75 & 0.01 & 0.20 & 354 & 0.74 & 1.28 & 0.10 & 0.21 & 0.44 & 0.35 & -0.03 & 0.27 \\
\hline & \multicolumn{14}{|c|}{ MODIS-Aqua } \\
\hline & \multicolumn{5}{|c|}{ Total AOD } & \multicolumn{5}{|c|}{ Coarse mode AOD } & \multicolumn{4}{|c|}{ Fine mode AOD } \\
\hline Seasons ${ }^{\mathrm{a}}$ & $N$ & $R$ & $a^{\mathrm{b}}$ & $b^{\mathrm{b}}$ & RMSD & $N$ & $R$ & $a^{\mathrm{b}}$ & $b^{\mathrm{b}}$ & RMSD & $R$ & $a^{\mathrm{b}}$ & $b^{\mathrm{b}}$ & RMSD \\
\hline MAM & 134 & 0.74 & 0.74 & 0.01 & 0.21 & 130 & 0.63 & 0.96 & 0.21 & 0.26 & 0.42 & 0.18 & -0.01 & 0.33 \\
\hline JJA & 30 & 0.71 & 0.48 & 0.17 & 0.18 & 29 & 0.71 & 0.60 & 0.24 & 0.20 & 0.09 & 0.05 & 0.02 & 0.20 \\
\hline SON & 52 & 0.72 & 0.62 & 0.1 & 0.15 & 48 & 0.74 & 1.16 & 0.16 & 0.20 & 0.35 & 0.24 & 0.04 & 0.24 \\
\hline DJF & 103 & 0.87 & 0.84 & -0.04 & 0.13 & 93 & 0.26 & 0.95 & 0.17 & 0.21 & 0.63 & 0.44 & -0.02 & 0.24 \\
\hline Overall & 319 & 0.77 & 0.72 & 0.03 & 0.18 & 300 & 0.66 & 0.95 & 0.19 & 0.26 & 0.44 & 0.27 & -0.01 & 0.28 \\
\hline
\end{tabular}

${ }^{\mathrm{a}}$ Spring (March, April, May), Summer (June, July, August), Autumn (September, October, November), Winter (December, January, February). ${ }^{\mathrm{b}} y=a x+b$. RMSD - Root mean square difference.

collection of MODIS data. Levy et al. (2007) have shown using 780 pairs of collocated data spread over 200 AERONET (AErosol RObotic NETwork; Holben et al., 1998) sites that the linear least square fit for MODIS vs. AERONET fine mode fraction has slope 1.051 , intercept -0.347 and $R^{2}$ 0.248. An interesting feature of their comparison has been a better match for absolute values of fine mode AOD implying poor determination of coarse mode AOD. This is in contrast to our finding where we have found better comparison for coarse mode and poor comparison for fine mode AOD. The linear least square fit parameters reported by Levy et al. (2007) for fine mode AOD are slope 0.95, intercept -0.023 and $R^{2} 0.781$. Possibly Levy et al. (2007) might have used only one or two sites of AERONET in India that existed after 2002 and before 2006. Hence, their result cannot be generalized for southern India. Jethva et al. (2010) carried out sensitivity and validation study of MODIS fine mode AOD using an AERONET station in northern India namely Kanpur. Jethva et al. (2010) have found a reasonable agreement for total AOD (slope 0.95 and $R^{2}=0.85$ ) but significant underestimation for fine mode AOD (slope 0.44 and $\left.R^{2}=0.58\right)$. Jethva et al. (2010) have reported that the slope of the least square fit for fine mode AOD increased from 0.44 to 0.62 when more absorbing type of aerosol model is used instead of default aerosol model (moderately absorbing type) in MODIS algorithm. They further report that the underestimation problem can be greatly reduced (slope 0.91 ) for fine mode AOD when more absorbing type of aerosol model is used together with the surface reflectance values incremented by $0.02($ at $0.66 \mu \mathrm{m})$. However, it should be mentioned that Jethva et al. (2010) have found the slope of regression for the total AOD greater than the one for summer and increasing the surface reflectance brought better agreement between AERONET and MODIS total AOD in their case, but over Gadanki the slope of regression for the total AOD is less than one for all seasons, hence increasing surface reflectance will worsen the comparison over Gadanki. Lee and Chung (2013) have compared the AERONET, MODIS and MISR fine mode fraction and have suggested a method to integrate groundbased observations with MODIS data to improve the accuracy of MODIS fine mode fraction. They also find comparison of MODIS vs. AERONET fine mode fraction poorly correlate $\left(R^{2}=0.19\right)$ if the improvement (data assimilation) as one suggested by them are not applied. Similar observations have been made for MISR fine mode fraction over land (Lee and Chung, 2013).

In Fig. 8, seasonal mean single scattering albedo (SSA) at $500 \mathrm{~nm}$ observed over Gadanki using sky-radiometer along with MODIS model SSA values at $550 \mathrm{~nm}$ for South Asia are shown. Since accuracy of SSA retrieval in sky-radiometer is dependent on magnitude of aerosol optical depth, only those SSA values are considered when AOD values are greater than 0.4. MODIS uses moderate absorbing type of aerosol model for fine mode and dust aerosol type for coarse mode over South Asia. They are kept the same for all seasons. MODIS SSA values for both coarse and fine mode are higher than sky-radiometer SSA values for all seasons. The difference of SSA values between sky-radiometer and MODIS is highest during summer and the lowest during winter. It is interesting to note that the correlation for total and fine mode AOD is highest when difference in SSA is lowest and vice-versa. This is also true for RMSD in case of total AOD (Table 1). 


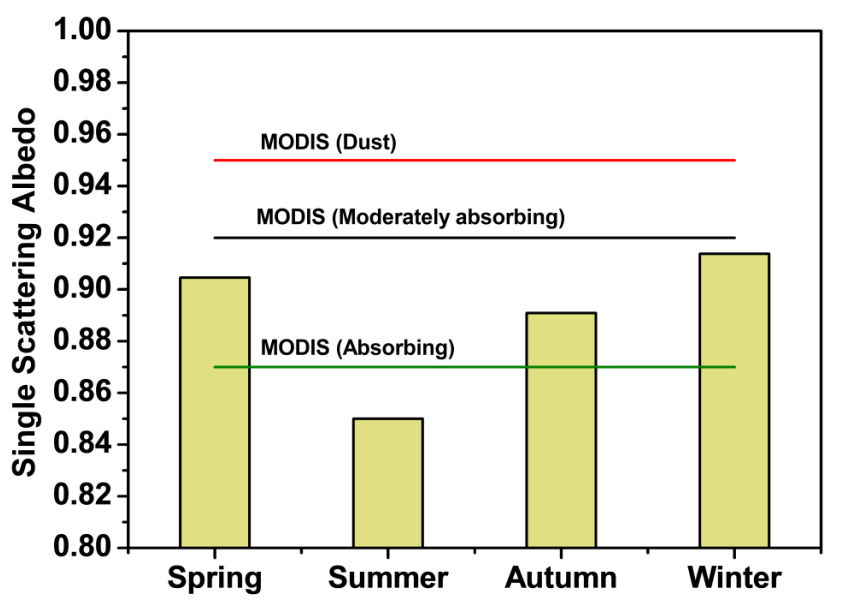

Fig. 8. Single scattering albedo of aerosol observed over Gadanki using sky-radiometer and model SSA values used in MODIS retrieval algorithm. Observed SSA values are at $500 \mathrm{~nm}$ whereas MODIS SSA values are at $550 \mathrm{~nm}$.

The slope of regression line for MODIS-Terra total AOD is close to one during summer, however this is due to large overestimation of coarse mode AOD and large underestimation of fine mode AOD during this period. There are less number of MODIS-Aqua data available during summer since summer over Gadanki is characterised by convective activities which leads to more cloudiness during afternoon and evening hours than morning. Earlier we suggested that cause of error for underestimation of AOD is due to selection of "less absorbing type" of aerosol model in MODIS look-up table for southern India (Kiran Kumar et al., 2013). Since, coarse mode AOD is overestimated and fine mode AOD is underestimated, both aerosol models that are moderately absorbing types for fine mode and dust type for coarse mode may not be appropriate models for southern India. MODIS algorithm uses the radiances measured from the top of the atmosphere to compare with calculated radiances which in turn rely on aerosol type. When a wrong aerosol type is assigned, for example, when real aerosols are absorbing type but the model uses moderate absorbing type of aerosol, then the calculated radiances will require less AOD in order to match with observed radiances. The reverse is also true, that is if the real aerosol are scattering type but the model uses absorbing type then the model will need higher values of AOD in order to match with observed radiances. Dust is an absorbing type of aerosol in comparison to sea-salt, whereas regions like southern India which are far away from the desert and having an ocean on three sides will have more sea-salt particles than dust particles. There has been few observational studies that show less amount of dust particles over southern India and significant presence of marine aerosols (e.g. Chatterjee et al., 2010; Ginoux et al., 2012). Seasonal mean SSA values over Gadanki vary from 0.85 to 0.91 . Current aerosol models for South Asia in MODIS have SSA values 0.92 for fine mode and 0.95 for coarse mode. Hence, no combination of them will ever be able to fit observed SSA, however if optical properties for fine mode is taken more absorbing type and for the other mode, if it is taken more scattering type then the combination may provide a better match with observed SSA. However, use of inappropriate aerosol models alone may not be able to account for all the observed differences between ground-based and MODIS AODs. Fine mode fraction retrieval is highly sensitive to surface reflectance as shown by Jethva et al. (2010). A $2 \%$ error in surface reflectance can produce an underestimation that is comparable to observed underestimation for Indian region (Jethva et al., 2010). It is important to note that unlike aerosol model which are assumed properties in the MODIS algorithm, surface reflectance values are retrieved in MODIS algorithm. The retrieval of surface reflectance in turn depends on the assumed aerosol properties. Further research is required to investigate the role of aerosol models on errors in retrieval of surface reflectance. Sensitivity of algorithm towards surface reflectance is aerosol model dependent. Jethva et al. (2010) have shown in the sensitivity study that if the surface reflectance is increased by a value 0.02 , regression slope for total AOD will be reduced from 0.95 to less than 0.85 over Kanpur when default aerosol model (moderately absorbing type) is used. However, the same increase in surface reflectance will produce regression slope close to 1 for absorbing type of fine mode aerosols. In other words for higher absorbing type of aerosol model, the algorithm is less sensitive towards surface reflectance.

\section{Conclusions}

MODIS derived AOD values have found significant usage from the aerosol science community as it provides unprecedented spatial and temporal coverage required for a variety of studies. Attempts were also made regularly to compare the MODIS derived aerosol products with the groundtruth data wherever available. However comprehensive validation studies comparing size resolved properties and single scattering albedo are very few particularly for the South Asian region. To the best of our knowledge, ours is the first study comparing the MODIS size resolved aerosol properties over southern India. In the present study, we have compared the MODIS derived AOD data with that obtained from operating a sky-radiometer from a remote rural location in southern India. The comparison reveals significant underestimation for total and fine mode AODs. While the comparison between MODIS-Terra and sky-radiometer total AODs shows correlation coefficient value of about 0.71 if one separates the AOD into fine and coarse mode, the comparison becomes very poor, particularly for the fine mode, with correlation coefficient value of 0.44 . The coarse mode AOD derived from MODIS-Terra and sky-radiometer compare better with a correlation coefficient value of 0.74 but 
values are over-estimated. Similar comparison is found for MODIS-Aqua. Seasonality of fine mode fraction is well captured in MODIS but values are less than one-half of the skyradiometer values. A part of the underestimation problem is related to assumptions of absorbing properties of aerosol in MODIS algorithm. MODIS uses bi-modal aerosol size distribution for South Asia that has SSA values 0.92 for fine mode and 0.95 for coarse mode, whereas seasonal mean SSA values are observed in range 0.85 to 0.91 Based on this, we suggest that instead of selecting a moderately absorbing aerosol type (as being done currently in the MODIS retrieval) a more absorbing aerosol type is better suited for fine mode aerosols, while reverse is true for the coarse mode aerosols, where instead of using 'dust aerosols' which is relatively a more absorbing type, usage of coarse sea-salt particles which is less absorbing is more appropriate for southern India.

Acknowledgements. Authors gratefully acknowledge the MODIS science team for providing AOD and fine mode fraction data and the GIOVANNI online data system, developed and maintained by the NASA GES DISC. Authors also gratefully acknowledge the NOAA/OAR/ESRL PSD, Boulder, Colorado, USA for providing long-term mean relative humidity and wind data from their web-site at http://www.esrl.noaa.gov/psd/ and OMI science team for providing total column ozone values over their web-site at http://ozoneaq.gsfc.nasa.gov/. Authors thank Department of Space, Govt. of India for their support. Authors thank Hiren Jethva and two anonymous reviewers for reviewing the manuscript and providing suggestions for improvement.

Edited by: P. Herckes

\section{References}

Bohren, C. F. and Huffman, D. R.: Absorption and scattering of light by small particles, Wiley-Interscience Publication, New York, USA, 530 pp., 1983.

Chatterjee, A., Jayaraman, A., Rao, T. N., and Raha, S.: In-cloud and below-cloud scavenging of aerosol ionic species over a tropical rural atmosphere in India, J. Atmos. Chem., 66, 27-40, doi:10.1007/s10874-011-9190-5, 2010.

Che, H., Shi, G., Uchiyama, A., Yamazaki, A., Chen, H., Goloub, P., and Zhang, X.: Intercomparison between aerosol optical properties by a PREDE skyradiometer and CIMEL sunphotometer over Beijing, China, Atmos. Chem. Phys., 8, 3199-3214, doi:10.5194/acp-8-3199-2008, 2008.

Corrigan, C. E., Ramanathan, V., and Schauer, J. J.: Impact of monsoon transitions on the physical and optical properties of aerosols, J. Geophys. Res.-Atmos., 111, D18208, doi:10.1029/2005JD006370, 2006.

Dubovik, O. and King, M. D.: A flexible inversion algorithm for retrieval of aerosol optical properties from Sun and sky radiance measurements, J. Geophys. Res., 105, 20673-20696, doi:10.1029/2000jd900282, 2000.

Dusek, U., Frank, G. P., Hildebrandt, L., Curtius, J., Schneider, J., Walter, S., Chand, D., Drewnick, F., Hings, S., Jung, D., Borrmann, S., and Andreae, M. O.: Size Matters More Than Chem- istry for Cloud-Nucleating Ability of Aerosol Particles, Science, 312, 1375-1378, doi:10.1126/science.1125261, 2006.

El-Metwally, M., Alfaro, S. C., Abdel Wahab, M. M., Zakey, A. S., and Chatenet, B.: Seasonal and inter-annual variability of the aerosol content in Cairo (Egypt) as deduced from the comparison of MODIS aerosol retrievals with direct AERONET measurements, Atmos. Res., 97, 14-25, doi:10.1016/j.atmosres.2010.03.003, 2010.

Estellés, V., Campanelli, M., Utrillas, M. P., Expósito, F., and Martínez-Lozano, J. A.: Comparison of AERONET and SKYRAD4.2 inversion products retrieved from a Cimel CE318 sunphotometer, Atmos. Meas. Tech., 5, 569-579, doi:10.5194/amt-5-569-2012, 2012.

Gadhavi, H. and Jayaraman, A.: Absorbing aerosols: contribution of biomass burning and implications for radiative forcing, Ann. Geophys., 28, 103-111, doi:10.5194/angeo-28-103-2010, 2010.

Ginoux, P., Prospero, J. M., Gill, T. E., Hsu, N. C., and Zhao, M.: Global-scale attribution of anthropogenic and natural dust sources and their emission rates based on MODIS Deep Blue aerosol products, Rev. Geophys., 50, RG3005, doi:10.1029/2012rg000388, 2012.

Hauser, A., Oesch, D., and Foppa, N.: Aerosol optical depth over land: Comparing AERONET, AVHRR and MODIS, Geophys. Res. Lett., 32, L17816, doi:10.1029/2005GL023579, 2005.

Haywood, J. and Boucher, O.: Estimates of the direct and indirect radiative forcing due to tropospheric aerosols: A review, Rev. Geophys., 38, 513-543, doi:10.1029/1999RG000078, 2000.

Holben, B. N., Eck, T. F., Slutsker, I., Tanré, D., Buis, J. P., Setzer, A., Vermote, E., Reagan, J. A., Kaufman, Y. J., Nakajima, T., Lavenu, F., Jankowiak, I., and Smirnov, A.: AERONET - A Federated Instrument Network and Data Archive for Aerosol Characterization, Remote Sens. Environ., 66, 1-16, doi:10.1016/S0034-4257(98)00031-5, 1998.

Hsu, N. C., Gautam, R., Sayer, A. M., Bettenhausen, C., Li, C., Jeong, M. J., Tsay, S.-C., and Holben, B. N.: Global and regional trends of aerosol optical depth over land and ocean using SeaWiFS measurements from 1997 to 2010, Atmos. Chem. Phys., 12, 8037-8053, doi:10.5194/acp-12-8037-2012, 2012.

Ichoku, C., Chu, A. D., Mattoo, S., Kaufman, Y. J., Remer, L. A., Tanré, D., Slutsker, I., and Holben, B. N.: A spatiotemporal approach for global validation and analysis of MODIS aerosol products, Geophys. Res. Lett., 29, MOD1.1-MOD1.4, doi:10.1029/2001GL013206, 2002.

Ignatov, A. M., Sapper, J., Cox, S., Laszlo, I., Nalli, N. R., and Kidwell, K. B.: Operational aerosol observations (AEROBS) from AVHRR/3 on board NOAA-KLM satellites, J. Atmos. Ocean. Tech., 21, 3-26, 2004.

Jayaraman, A., Gadhavi, H., Ganguly, D., Misra, A., Ramachandran, S., and Rajesh, T. A.: Spatial variations in aerosol characteristics and regional radiative forcing over India: Measurements and modeling of 2004 road campaign experiment, Atmos. Environ., 40, 6504-6515, doi:10.1016/j.atmosenv.2006.01.034, 2006.

Jethva, H., Satheesh, S. K., and Srinivasan, J.: Evaluation of Moderate-Resolution Imaging Spectroradiometer (MODIS) Collection 004 (C004) aerosol retrievals at Kanpur, Indo-Gangetic Basin, J. Geophys. Res., 112, D14216, doi:10.1029/2006JD007929, 2007.

Jethva, H., Satheesh, S. K., Srinivasan, J., and Levy, R. C.: Improved retrieval of aerosol size-resolved properties from moderate res- 
olution imaging spectroradiometer over India: Role of aerosol model and surface reflectance, J. Geophys. Res., 115, D18213, doi:10.1029/2009jd013218, 2010.

Kahn, R. A., Gaitley, B. J., Garay, M. J., Diner, D. J., Eck, T. F., Smirnov, A., and Holben, B. N.: Multiangle Imaging SpectroRadiometer global aerosol product assessment by comparison with the Aerosol Robotic Network, J. Geophys. Res., 115, D23209, doi:10.1029/2010JD014601, 2010.

Kalnay, E., Kanamitsu, M., Kistler, R., Collins, W., Deaven, D., Gandin, L., Iredell, M., Saha, S., White, G., Woollen, J., Zhu, Y., Leetmaa, A., Reynolds, B., Chelliah, M., Ebisuzaki, W., Higgins, W., Janowiak, J., Mo, K. C., Ropelewski, C., Wang, J., Jenne, R., and Joseph, D.: The NCEP/NCAR 40-Year Reanalysis Project, B. Am. Meteorol. Soc., 77, 437-472, doi:10.1175/15200477(1996)077<0437:TNYRP>2.0.CO;2, 1996.

Kaskaoutis, D. G., Nastos, P. T., Kosmopoulos, P. G., and Kambezidis, H. D.: Characterising the long-range transport mechanisms of different aerosol types over Athens, Greece during 2000-2005, Int. J. Climatol., 32, 1249-1270, doi:10.1002/joc.2357, 2012.

Kharol, S. K., Badarinath, K. V. S., Sharma, A. R., Kaskaoutis, D. G., and Kambezidis, H. D.: Multiyear analysis of Terra/Aqua MODIS aerosol optical depth and ground observations over tropical urban region of Hyderabad, India, Atmos. Environ., 45, 1532-1542, doi:10.1016/j.atmosenv.2010.12.047, 2011.

Kim, D.-H., Sohn, B.-J., Nakajima, T., Takamura, T., Takemura, T., Choi, B.-C., and Yoon, S.-C.: Aerosol optical properties over east Asia determined from ground-based sky radiation measurements, J. Geophys. Res., 109, D02209, doi:10.1029/2003jd003387, 2004.

Kiran Kumar, T., Gadhavi, H., Jayaraman, A., Sai Suman, M. N., and Vijaya Bhaskara Rao, S.: Temporal and spatial variability of aerosol optical depth over South India as inferred from MODIS, J. Atmos. Sol.-Terr. Phys., 94, 71-80, doi:10.1016/j.jastp.2012.12.010, 2013.

Kokhanovsky, A. A., Breon, F. M., Cacciari, A., Carboni, E., Diner, D., Di Nicolantonio, W., Grainger, R. G., Grey, W. M. F., Höller, R., Lee, K. H., Li, Z., North, P. R. J., Sayer, A. M., Thomas, G. E., and von Hoyningen-Huene, W.: Aerosol remote sensing over land: A comparison of satellite retrievals using different algorithms and instruments, Atmos. Res., 85, 372-394, doi:10.1016/j.atmosres.2007.02.008, 2007.

Kosmopoulos, P. G., Kaskaoutis, D. G., Nastos, P. T., and Kambezidis, H. D.: Seasonal variation of columnar aerosol optical properties over Athens, Greece, based on MODIS data, Remote Sens. Environ., 112, 2354-2366, doi:10.1016/j.rse.2007.11.006, 2008.

Laszlo, I., Liu, H., and Ignatov, A.: Comparison of singlechannel and multichannel aerosol optical depths derived from MAPSS data, J. Geophys. Res., 113, D19S90, doi:10.1029/2007JD009664, 2008.

Lee, J., Kim, J., Song, C. H., Kim, S. B., Chun, Y., Sohn, B. J., and Holben, B. N.: Characteristics of aerosol types from AERONET sunphotometer measurements, Atmos. Environ., 44, 3110-3117, doi:10.1016/j.atmosenv.2010.05.035, 2010.

Lee, K. and Chung, C. E.: Observationally-constrained estimates of global fine-mode AOD, Atmos. Chem. Phys., 13, 2907-2921, doi:10.5194/acp-13-2907-2013, 2013.
Levy, R. C., Remer, L. A., Mattoo, S., Vermote, E. F., and Kaufman, Y. J.: Second-generation operational algorithm: Retrieval of aerosol properties over land from inversion of Moderate Resolution Imaging Spectroradiometer spectral reflectance, J. Geophys. Res., 112, D13211, doi:10.1029/2006JD007811, 2007.

Levy, R. C., Remer, L. A., Tanré, D., Mattoo, S., and Kaufman, Y. J.: Algorithm for remote sensing of tropospheric aerosol over dark targets from MODIS: Collection 005 and 051: Revision 2 Feb 2009, MODIS Algorithm Theoretical Basis Document, GSFC/NASA, Greenbelt, MD, 20771, USA, 96 pp., 2009.

Levy, R. C., Remer, L. A., Kleidman, R. G., Mattoo, S., Ichoku, C., Kahn, R., and Eck, T. F.: Global evaluation of the Collection 5 MODIS dark-target aerosol products over land, Atmos. Chem. Phys., 10, 10399-10420, doi:10.5194/acp-10-10399-2010, 2010.

Livingston, J. M., Redemann, J., Russell, P. B., Torres, O., Veihelmann, B., Veefkind, P., Braak, R., Smirnov, A., Remer, L., Bergstrom, R. W., Coddington, O., Schmidt, K. S., Pilewskie, P., Johnson, R., and Zhang, Q.: Comparison of aerosol optical depths from the Ozone Monitoring Instrument (OMI) on Aura with results from airborne sunphotometry, other space and ground measurements during MILAGRO/INTEX-B, Atmos. Chem. Phys., 9, 6743-6765, doi:10.5194/acp-9-6743-2009, 2009.

Martonchik, J. V., Diner, D. J., Kahn, R. A., Ackerman, T. P., Verstraete, M. M., Pinty, B., and Gordon, H. R.: Techniques for the retrieval of aerosol properties over land and ocean using multiangle imaging, IEEE T. Geosci. Remote Sens., 36, 1212-1227, 1998.

Misra, A., Jayaraman, A., and Ganguly, D.: Validation of MODIS derived aerosol optical depth over Western India, J. Geophys. Res., 113, D04203, doi:10.1029/2007JD009075, 2008.

Nakajima, T., Tonna, G., Rao, R., Boi, P., Kaufman, Y., and Holben, B.: Use of sky brightness measurements from ground for remote sensing of particulate polydispersions, Appl. Optics, 35, 2672 2686, doi:10.1364/AO.35.002672, 1996.

O’Neill, N. T., Eck, T. F., Smirnov, A., Holben, B. N., and Thulasiraman, S.: Spectral discrimination of coarse and fine mode optical depth, J. Geophys. Res., 108, 4559, doi:10.1029/2002jd002975, 2003.

Rajeev, K., Parameswaran, K., Thampi, B. V., Mishra, M. K., Nair, A. K., and Meenu, S.: Altitude distribution of aerosols over Southeast Arabian Sea coast during premonsoon season: Elevated layers, long-range transport and atmospheric radiative heating, Atmos. Environ., 44, 2597-2604, doi:10.1016/j.atmosenv.2010.04.014, 2010.

Ramanathan, V., Crutzen, P. J., Kiehl, J. T., and Rosenfeld, D.: Aerosols, Climate, and the Hydrological Cycle, Science, 294, 2119-2124, doi:10.1126/science.1064034, 2001.

Remer, L. A., Kaufman, Y. J., Tanré, D., Mattoo, S., Chu, D. A., Martins, J. V., Li, R. R., Ichoku, C., Levy, R. C., Kleidman, R. G., Eck, T. F., Vermote, E., and Holben, B. N.: The MODIS Aerosol Algorithm, Products, and Validation, J. Atmos. Sci., 62, 947-973, doi:10.1175/JAS3385.1, 2005.

Remer, L. A., Kleidman, R. G., Levy, R. C., Kaufman, Y. J., Tanré, D., Mattoo, S., Martins, V. J., Ichoku, C., Koren, I., Yu, H., and Holben, B. N.: Global aerosol climatology from the MODIS satellite sensors, J. Geophys. Res., 113, D14S07, doi:10.1029/2007JD009661, 2008. 
Ruzer, L. S. and Harley, N. H. (Eds.): Aerosols Handbook: Measurement, Dosimetry, and Health Effects, CRC Press, Boca Raton, FL 33487-2742, 728 pp., 2004.

Sinha, P. R., Kaskaoutis, D. G., Manchanda, R. K., and Sreenivasan, S.: Characteristics of aerosols over Hyderabad in southern Peninsular India: synergy in the classification techniques, Ann. Geophys., 30, 1393-1410, doi:10.5194/angeo-30-1393-2012, 2012.

Suresh Babu, S., Krishna Moorthy, K., and Satheesh, S. K.: Temporal heterogeneity in aerosol characteristics and the resulting radiative impacts at a tropical coastal station - Part 2: Direct short wave radiative forcing, Ann. Geophys., 25, 2309-2320, doi:10.5194/angeo-25-2309-2007, 2007.

Tanré, D., Bréon, F. M., Deuzé, J. L., Dubovik, O., Ducos, F., François, P., Goloub, P., Herman, M., Lifermann, A., and Waquet, F.: Remote sensing of aerosols by using polarized, directional and spectral measurements within the A-Train: the PARASOL mission, Atmos. Meas. Tech., 4, 1383-1395, doi:10.5194/amt-4-1383-2011, 2011.
Torres, O., Tanskanen, A., Veihelmann, B., Ahn, C., Braak, R., Bhartia, P. K., Veefkind, P., and Levelt, P.: Aerosols and surface UV products from Ozone Monitoring Instrument observations: An overview, J. Geophys. Res., 112, D24S47, doi:10.1029/2007JD008809, 2007.

Tripathi, S. N., Dey, Sagnik, Chandel, A., Srivastava, S., Singh, Ramesh P., and Holben, B. N.: Comparison of MODIS and AERONET derived aerosol optical depth over the Ganga Basin, India, Ann. Geophys., 23, 1093-1101, doi:10.5194/angeo-231093-2005, 2005. 